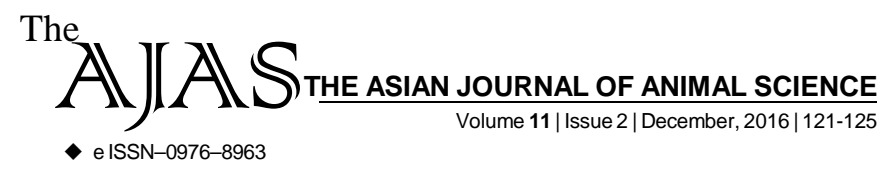

DOI : 10.15740/HAS/TAJAS/11.2/121-125
Visit us | www.researchjournal.co.in

RESEARCH ARTICLE........

\title{
Mosquito dol Nets of Ratnagiri, Maharashtra
}

N.M. WARHEKAR AND A.S. MOHITE

\begin{abstract}
,
Author for Corresponding -

\section{N.M. WARHEKAR}

ABSTRACT...... Dol net fishing is one of the popular fishing methods along the west coast of India. However, there are regional variations in their design, construction and operation. The present study deals with the general characteristics and design of mosquito dol nets operated in creeks of Ratnagiri, Maharashtra. The nets were made of webbing of polyethylene (PE) multifilament of $1.5 \mathrm{~mm}$ diameter with specifications of 210DX5X3 and having mesh size ranging from 150 to $8 \mathrm{~mm}$. The nets were operated in the creek throughout the year in the depth ranging from 18 to $20 \mathrm{~m}$.
\end{abstract}

Department of Fisheries Engineering, College of Fisheries (Dr. B.S.K.K.V.), Shirgaon, RATNAGIRI (M.S.) INDIA

Email: nilwarhekar@gmail.com

See end of the article for

Coopted authors'
KEY WORDS...... Design, General characteristics, Mosquito dol net, Polyethylene

HOW TO CITE THIS ARTICLE - Warhekar, N.M. and Mohite, A.S. (2016). Mosquito dol Nets of Ratnagiri, Maharashtra. Asian J. Animal Sci., 11(2): 121-125. DOI : 10.15740/HAS/TAJAS/11.2/121125.

ARTICLE CHRONICLE - Received : 25.05.2016; Revised : 24.10.2016; Accepted : 07.11.2016 